Nafta-Gaz 2020, nr 7, s. 466-473, DOI: 10.18668/NG.2020.07.05

\title{
Zmiana wczesnej wytrzymałości na ściskanie pod wpływem wybranych środków poprawiających stabilność sedymentacyjną
}

\author{
Change of early compressive strength under the influence of selected agents improving \\ sedimentation stability
}

\author{
Marcin Kremieniewski \\ Instytut Nafty i Gazu -Państwowy Instytut Badawczy
}

\begin{abstract}
STRESZCZENIE: Zaczyny o obniżonej gęstości są najczęściej stosowanymi recepturami w przypadku uszczelniania kolumn rur okładzinowych w warunkach obniżonego ciśnienia złożowego czy w strefach słabozwięzłych. Odpowiednio obniżona gęstość zaczynu pozwala na zredukowanie ciśnienia hydrostatycznego zaczynu cementowego, dzięki czemu nie zachodzi ryzyko ucieczki cementu w strefy słabo zwięzłe. Zaczyny lekkie mogą być również z powodzeniem stosowane do uszczelniania głębokich odwiertów, gdzie zachodzi konieczność wtłoczenia zaczynu na dużą głębokość. Wówczas stosowane są dwie receptury: pierwszym zaczynem jest zaczyn lekki, po którym tłoczony jest zaczyn o większej gęstości. W celu obniżenia gęstości zaczynu stosuje się różnego rodzaju lekkie dodatki wypełniające, których obecność w zaczynie powoduje zmniejszenie jego gęstości. Jednakże po zastosowaniu lekkich materiałów wypełniających zaczyn często ulega frakcjonowaniu, co objawia się oddzielaniem lekkich frakcji w górnej części cementowanej przestrzeni pierścieniowej lub pozarurowej oraz opadaniem w dolne partie ciężkich frakcji zaczynu. W celu wyeliminowania tego niepożądanego zjawiska stosuje się środki, które na skutek zwiększenia lepkości wody zarobowej, a następnie wzrostu wytrzymałości strukturalnej zaczynu powodują poprawę stabilności sedymentacyjnej opracowywanej receptury zaczynu. Jednakże obecność tych środków wpływa na zmianę wartości wczesnej wytrzymałości mechanicznej tworzącego się z zaczynu płaszcza cementowego, a parametr ten jest szczególnie istotny w przypadku tego rodzaju zaczynów. Ponadto środki przeciwsedymentacyjne powodują zmianę czasu wiązania zaczynu, który to parametr jest istotny z technologicznego punktu widzenia (dostosowanie czasu tłoczenia do czasu niezbędnego na przeprowadzenie zabiegu cementowania). W związku z powyższym w niniejszej publikacji poruszono zagadnienie zmiany wartości wczesnej wytrzymałości na ściskanie pod wpływem wybranych środków poprawiających stabilność sedymentacyjną. W artykule omówiono wyniki badań czterech rodzajów środków poprawiających stabilność sedymentacyjną. Przeprowadzone zostały badania dla zaczynów kontrolnych sporządzonych na bazie dwóch rodzajów cementów: cement klasy CEM I 42,5R oraz cement glinowo-wapniowy. Badaniom poddano głównie czas wiązania, czas przejścia od wartości początku wiązania do wartości końca wiązania oraz wytrzymałość na ściskanie po 24 godzinach hydratacji próbki. Na podstawie zrealizowanych badań określono wpływ środków poprawiających stabilność sedymentacyjną na wartość wczesnej wytrzymałości na ściskanie.
\end{abstract}

Słowa kluczowe: Zaczyn cementowy, stabilność sedymentacyjna, frakcjonowanie, czas wiązania, początek wiązania, koniec wiązania, wytrzymałość na ściskanie.

ABSTRACT: Low density cement slurries are the most commonly used formulas for sealing casing pipe columns in conditions of reduced reservoir pressure or in low-density zones. Appropriately reduced cement slurry density allows the hydrostatic pressure of the cement slurry to be reduced, so that there is no risk of cement escaping into areas with poor compactness. Lightweight cement slurries can be also successfully used for sealing deep wells, where it is necessary to press the cement slurry to a great depth. Two recipes are used in such a case: the first cement slurry is lightweight slurry, followed by a cement slurry of higher density. In order to reduce the density of the slurry, various types of light fillers are used, whose presence in the slurry reduces its density. However, when lightweight filler materials are used, the slurry fractionates, which is manifested in the separation of light fractions in the upper part of the cemented annular or space between particular casing and settling to the lower parts of the heavy slurry fractions. In order to eliminate this undesirable phenomenon, agents are used which, due to the increase in the viscosity of the mixing water, followed by an increase in the structural strength of the stone, result in improved sedimentation stability of the developed cement slurry recipe. However, the presence of these agents changes the value of early mechanical strength formed from the cement slurry sheath, and this parameter is particularly important for this type of cement slurries. In addition, anti-sedimentation agents cause a change in the cement slurry

Autor do korespondencji: M. Kremieniewski, e-mail: marcin.kremieniewski@inig.pl Artykuł nadesłano do Redakcji: 02.01.2020 r. Zatwierdzono do druku: 18.06.2020 r. 
setting time, and this parameter is important from a technological point of view (adjusting the circulating time to the time necessary to carry out the cementing operation). Therefore, this publication discusses the issue of changing the value of early compressive strength under the influence of selected agents improving sedimentation stability. The article discusses the results of testing four types of agents that improve sedimentation stability. Tests were carried out for control cement slurries prepared on the basis of two types of cement, CEM I 42.5R cement and aluminum-calcium cement. The tests included mainly the thickening time, transition time from the value of the thickening start to the value of the thickening end and compressive strength after 24 hours of sample hydration. Based on the research carried out, the impact of agents improving sedimentation stability on the value of early compressive strength was determined.

Key words: cement slurry, sedimentation stability, fractionation, setting time, start of setting, end of setting, compressive strength

\section{Wprowadzenie}

Odpowiednio przeprowadzone rurowanie, a następnie uszczelnienie otworu nabiera zasadniczego znaczenia na złożach o niskim ciśnieniu złożowym lub w strefach chłonnych. Jest to związane z koniecznością stosowania zaczynu o obniżonej gęstości, którego skład jest wzbogacany o dodatki lekkich frakcji (Jordan et al., 2018; Kremieniewski, 2018a, 2019a). W ostatnich latach pojawił się szereg nowych opracowań teoretycznych, jak również nowości technologicznych w zakresie sporządzania receptur lekkich zaczynów cementowych (Falode et al., 2013; Kremieniewski et al., 2016; Kremieniewski i Kędzierski, 2019). Jednak mimo stosowanych nowoczesnych środków poprawiających parametry płynnych zaczynów cementowych w dalszym ciągu występują problemy dotyczące uzyskania odpowiednich wartości parametrów technologicznych tego rodzaju zaczynów. Ze względu na obecność wypełniaczy lekkich zaczyny mogą wykazywać frakcjonowanie i tym samym brak stabilności sedymentacyjnej (Carathers i Crook, 1987; Peng i Jacobsen, 2013; Kremieniewski, 2017, 2019b). Powyższe znajduje przełożenie na występowanie anizotropii w strukturze zarówno świeżego, jak i stwardniałego zaczynu. W przypadku zaczynu w formie płynnej, dodatek mikrosfery może ulegać oddzieleniu od zaczynu i unosić się w jego górnej części (rys. 1) przez co występuje różnica gęstości

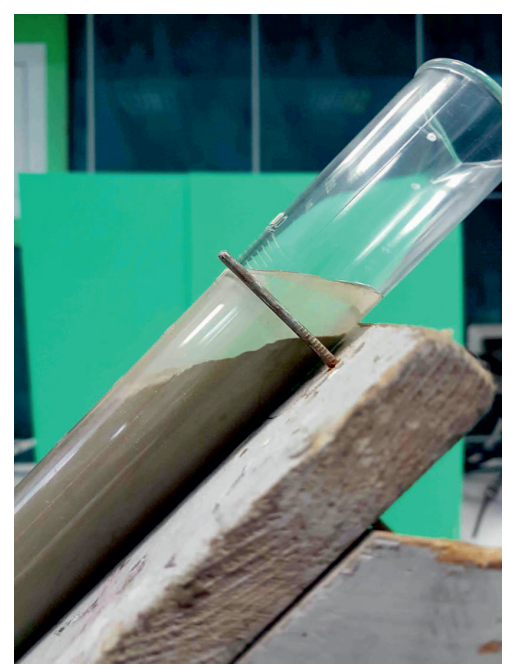

Rys. 1. Nadmierne frakcjonowanie zaczynu

Fig. 1. Excessive fractionation of the cement slurry w górnej i dolnej części cementowanego interwału. Ponadto odfiltrowywanie cieczy z zaczynu w przewiercane warstwy może skutkować zakolmatowaniem strefy przyodwiertowej (Raczkowski et al., 1978; Półchłopek, 1993; Wiśniowski et al., 2007; Rzepka et al., 2012). Różnice w gęstości zaczynu i brak jednorodności powstały na skutek frakcjonowania zaczynu. Powoduje to również zróżnicowanie w czasie wiązania pomiędzy górną częścią płaszcza cementowego, a jego dolną partią. Z kolei po stwardnieniu w związanym zaczynie cementowym różnice pojawiają się w parametrach mechanicznych, takich jak np.: wytrzymałość na ściskanie, wytrzymałość na zginanie lub przyczepność do rur stalowych. Różnice te widoczne są także w przepuszczalności dla gazu oraz we współczynniku porowatości (Bensted, 1978; Herianto i Fathaddin, 2005; Labibzadeh et al., 2010; Stryczek i in. 2011; Kremieniewski, 2019e). Wymagane jest, aby płaszcz cementowy po związaniu posiadał odpowiednią (min. $14 \mathrm{MPa}$ ) wytrzymałość na ściskanie przed przystąpieniem do pomiarów stanu zacementowania. Jednak w przypadku zastosowania zaczynu, który nie wykazuje stabilności sedymentacyjnej może się zdarzyć, że w górnej części zaczyn miał znacznie niższe wartości wytrzymałości niż w dolnych partiach (Bensted, 2004; Stryczek et al., 2005; Rzepka i Stryczek, 2008; Kremieniewski, 2019c, 2019f). Efektem powyższego będzie zapis z pomiarów RBT braku cementu w uszczelnianej przestrzeni pierścieniowej lub słabe zacementowanie, pomimo że w trakcie cementowania „zaczyn wyszedł do wierzchu”. Taki stan uszczelnienia otworu przedstawiono na rysunku 2. Ze względu na mocne frakcjonowanie zaczynów o obniżonej gęstości z dodatkami lekkimi, wymagane jest zastosowanie różnego rodzaju środków pozwalających na utrzymanie frakcji o różnych gęstościach w całej objętości zaczynu (Nelson, 1990; Lapasin et al., 1995; Risica et al., 2010; Kremieniewski, 2018b). Materiały tego rodzaju mające przeciwdziałać wytrącaniu cząsteczek powodują utrzymanie stabilnej wartości granicy płynności na poziomie umożliwiającym utrzymanie cyrkulacji oraz oporów hydraulicznych niepowodujących wywołania szczelinowania bądź podobnych komplikacji (Stryczek et al., 2009; Kremieniewski, 2018c). Najczęściej stosowanym środkiem jest bentonit, którego niewielkie ilości zapobiegają wytrącaniu cząsteczek z zaczynu cementowego. Dzięki warstwowej budowie minerałów 
ilastych z grupy smektytów, będących głównym składnikiem bentonitu, środek ten wykazuje właściwości adsorpcyjne dużych ilości wody, co powoduje homogenizację zaczynu cementowego. Powyższe skutkuje możliwością nawet kilkukrotnej ekspansji pierwotnej objętości bentonitu, dzięki czemu

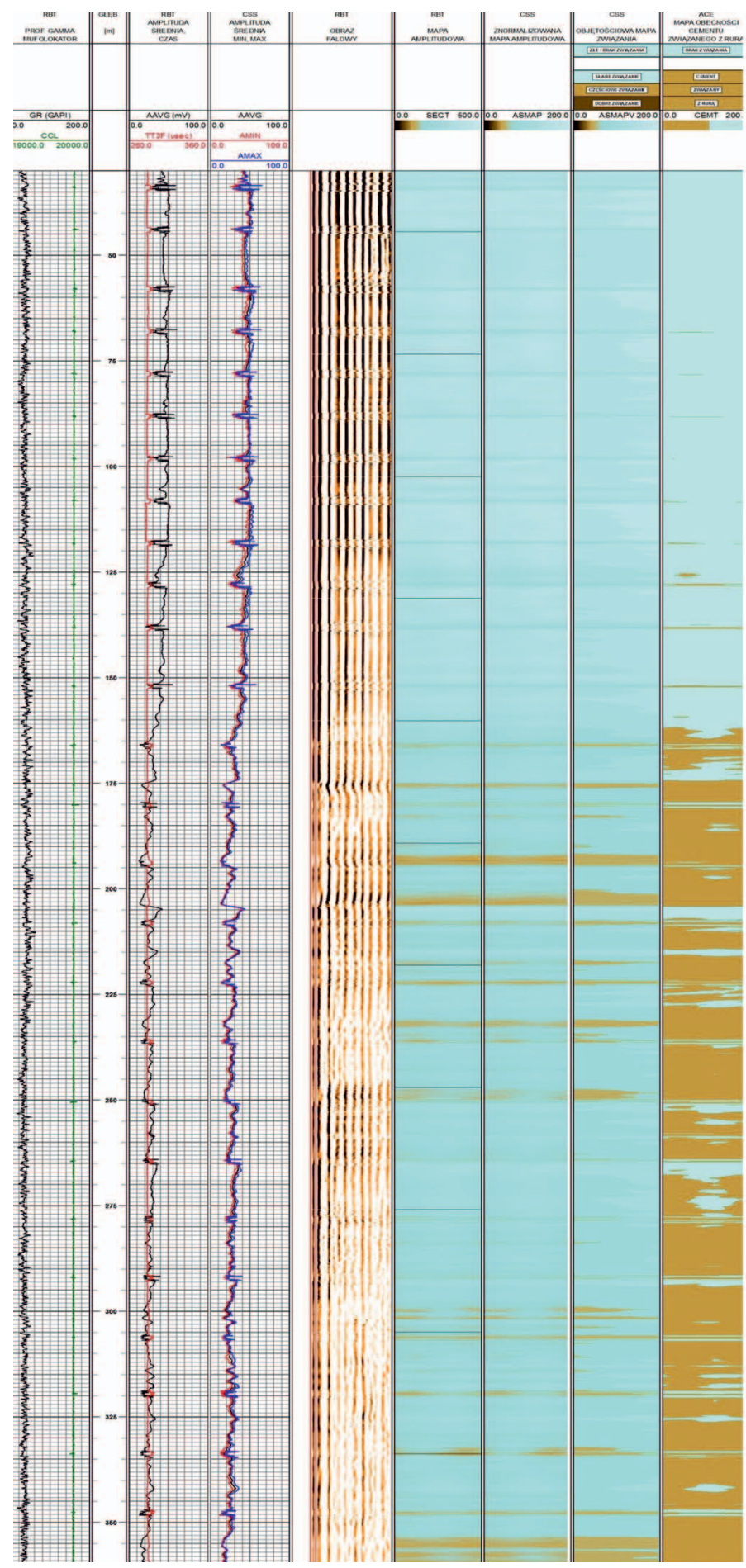

Rys. 2. Obraz stanu zacementowania otworu (RBT) przez zaczyn o nadmiernym frakcjonowaniu (kolorem niebieskim zaznaczono widoczne w górnej części fragmenty świadczące o braku cementu w przestrzeni pierścieniowej)

Fig. 2. Cement bond logging of the hole by the cement slurry with excessive fractionation (the fragments visible in the upper part indicating the lack of cement in the annular space are marked in blue) możliwe jest zwiększenie lepkości cieczy zarobowej, wytrzymałości strukturalnej zaczynu i tym samym utrzymanie fazy stałej w całej objętości tłoczonego zaczynu cementowego (Kremieniewski 2019d; Stryczek et al., 2014). Jednak domieszka bentonitu do zaczynu w zależności od koncentracji może powodować zmianę wytrzymałości mechanicznej tworzącego się płaszcza cementowego.

W celu poprawy stabilności sedymentacyjnej można użyć wodną dyspersję bezpostaciowej krzemionki zwaną powszechnie szkłem wodnym. Jest to ciecz o gęstości $1,23 \mathrm{~g} / \mathrm{cm}^{3}$ zawierająca mikrokrzemionkę o bardzo rozwiniętej powierzchni właściwej, dzięki czemu działa stabilizująco w zaczynach cementowych zmniejszając skłonność do sedymentacji poprzez swoje właściwości zagęszczające i tiksotropowe (Kurdowski, 2010; Stryczek et al., 2016; Kremieniewski i Stryczek, 2019). Możliwe jest również zastosowanie wielkocząsteczkowych środków polimerowych o zazwyczaj ,zakodowanym” przez dystrybutorów składzie. Ich działanie opiera się na zwiększeniu lepkości wody zarobowej i wytrzymałości strukturalnej zaczynu, co pozwala na wyeliminowanie frakcjonowania lekkich cząstek w płynnym zaczynie cementowym (Lapasin et al., 1995; Risica et al., 2010).

Niezależnie od rodzaju środków stosowanych w celu poprawy stabilności sedymentacyjnej zaczynu, wywierają one znaczny wpływ na jego parametry technologiczne. Biorąc pod uwagę fakt, że środki te są stosowane głównie w zaczynach lekkich, w których bardzo trudne jest uzyskanie wymaganych wartości parametrów mechanicznych, to w dalszej części niniejszej publikacji omówiono wpływ wybranych środków poprawiających stabilność sedymentacyjną zaczynu na zmianę wczesnej wytrzymałości na ściskanie.

\section{Przebieg prac badawczych}

Prace badawcze, których celem było określenie zmiany wczesnej wytrzymałości na ściskanie pod wpływem środków poprawiających stabilność sedymentacyjną, zrealizowane zostały w Laboratorium Zaczynów Uszczelniających INiG - PIB w oparciu o normy: PN-85/G-02320 Cementy i zaczyny cementowe do cementowania $w$ otworach wiertniczych; PN-EN 10426-2 Przemyst naftowy i gazowniczy. Cementy i materiaty do cementowania otworów. Część 2: Badania cementów wiertniczych oraz API SPEC 10 Specification for materials and testing for well cements.

Celem prac badawczych, które omówione zostały w niniejszej publikacji, było wykazanie wpływu wybranych środków poprawiających stabilność sedymentacyjną na zmianę wytrzymałości mechanicznej po 24 godzinach hydratacji. Zagadnienie to jest istotne, ponieważ wartości wczesnej wytrzymałości na ściskanie są bardzo ważne z punktu widzenia 
możliwości przystąpienia do dalszych prac realizacji otworu po związaniu zaczynu. Dodatkowo uzyskanie podwyższonych wartości wczesnej wytrzymałości pozwala stwierdzić o możliwości zastosowania danego środka pod kątem zwiększenia parametrów mechanicznych zaczynów lekkich. A tego rodzaju receptury charakteryzują się zazwyczaj niskimi wartościami wytrzymałości w początkowym okresie hydratacji.

W niniejszej publikacji omówiono wyniki badań przeprowadzonych dla próbek zaczynów cementowych, które sporządzono na bazie dwóch różnych rodzajów cementów. Pierwszym był cement portlandzki klasy CEM I 42,5R, który jest najczęściej stosowany w warunkach przemysłowych. Natomiast drugim rodzajem spoiwa był cement glinowo-wapniowy firmy REWA o zawartości tlenku glinu 50\%. Cement ten został poddany badaniom ze względu na fakt, iż podwyższona ilość tlenku glinu powoduje skrócenie czasu wiązania zaczynu cementowego i może powodować poprawę jego parametrów mechanicznych. Podczas badań skoncentrowano się na określeniu czasu początku wiązania $\left(T_{P W}\right)$ i czasu końca wiązania $\left(T_{K W}\right)$. Określono również czas przejścia od wartości $T_{P W}$ do wartości $T_{K W}$, a w końcowym etapie zbadano wytrzymałość mechaniczną stwardniałego zaczynu cementowego. Próbki hydratyzowały w temperaturze $25^{\circ} \mathrm{C}$ w ciśnieniu atmosferycznym. Wodą zaborową była woda wodociągowa.

Podczas oceny wpływu środków poprawiających stabilność sedymentacyjną na czas wiązania oraz wczesną wytrzymałość mechaniczną stwardniałego zaczynu cementowego przeprowadzone zostały badania dla 10 receptur, po 5 zaczynów dla każdego rodzaju cementu. Pierwsza receptura to zaczyn kontrolny, który nie zawierał środków przeciwsedymentacyjnych. Badane zaczyny sporządzono na bazie cementu portlandzkiego klasy CEM I 42,5R, a współczynnik wodno-cementowy wynosił 0,46.
W badanych recepturach zastosowano 4\% domieszki środków przeciwsedymentacyjnych. Domieszka o zakodowanej nazwie ZKCD została użyta w koncentracji wynoszącej $0,1 \%$, ponieważ większa jej ilość powodowała mocne zagęszczenie zaczynu. Składy i uzyskane wyniki badań zestawiono w tabelach 1 i 2.

Porównując uzyskane wyniki badań czasu wiązania zaobserwowano zróżnicowane działanie środków poprawiających stabilność sedymentacyjną zaczynów. Stwierdzono, że 4\% domieszka środka PG (pr. nr 2) spowodowała wydłużenie czasu początku wiązania oraz końca wiązania w stosunku do próbki kontrolnej (rys. 3; pr. nr 1), jednak czas przejścia od wartości $T_{P W}$ do wartości $T_{K W}$ uległ najmocniejszemu skróceniu ze wszystkich badanych środków (rys. 4; pr. nr 2). Zastosowanie tego środka spowodowało również obniżenie wartości wytrzymałości na ściskanie w porównaniu do próbki bazowej, co przedstawiono na rysunku 4 (pr. 2). Wprowadzenie do receptury zaczynu kolejnego środka przeciwsedymentacyjnego BB6 skutkowało nieznacznym wydłużeniem wartości czasu początku wiązania i skróceniem czasu końca wiązania (rys. 3; pr. nr 3) w stosunku do próbki bazowej. Takie działanie 4\%owej koncentracji środka BB6 spowodowało skrócenie czasu przejścia od wartości $T_{P W}$ do wartości $T_{K W}$ (rys. 4) i dodatkowo uzyskano najwyższą z badanych próbek na bazie cementu CEM I 42,5R wartość wytrzymałości na ściskanie, która wynosiła $20 \mathrm{MPa}$ (rys. 5). Kolejny środek przeciwsedymentacyjny LP102 zastosowany w koncentracji 4\%, spowodował wydłużenie wartości czasu początku wiązania i końca wiązania (rys. 3), a także wydłużenie czasu przejścia od $T_{P W}$ do $T_{K W}$ (rys. 4). Wartość wczesnej wytrzymałości mechanicznej po zastosowaniu LP102 była niższa niż próbki kontrolnej (rys. 5). Ostatnią z badanych domieszek przeciwsedymentacyjnych był ZCKD, który zastosowano w koncentracji 0,1\%. Obecność tego

Tabela 1. Badania różnego rodzaju środków o działaniu poprawiającym stabilność sedymentacyjną zaczynu (spoiwo wiążące - cement CEM I 42,5R)

Table 1. Tests of various types of agents that improve the sedimentation stability of the cement slurry (CEM 42.5R cement)

\begin{tabular}{|c|c|c|c|c|c|c|c|c|}
\hline \multirow{3}{*}{$\begin{array}{c}\mathrm{Nr} \\
\text { próbki }\end{array}$} & \multirow{3}{*}{$\begin{array}{c}\text { Rodzaj cementu = } \\
\text { Współczynnik } \\
\text { wodno-cementowy }\end{array}$} & \multirow{3}{*}{$\begin{array}{l}\text { Udzial } \\
\text { cementu }\end{array}$} & \multirow{3}{*}{$\begin{array}{c}\text { Rodzaj } \\
\text { domieszki }\end{array}$} & \multirow[b]{2}{*}{$\begin{array}{c}\text { Udział } \\
\text { domieszki }\end{array}$} & \multicolumn{2}{|c|}{ Czas wiązania } & \multirow{2}{*}{$\begin{array}{c}\text { Czas } \\
\text { przejścia } \\
\text { od PW do KW }\end{array}$} & \multirow{2}{*}{$\begin{array}{c}\text { Wytrzymałość na } \\
\text { ściskanie (średnia } \\
\text { arytmetyczna) } \\
2 \text { dni hydratacji }\end{array}$} \\
\hline & & & & & $\begin{array}{c}\text { Początek } \\
\text { wiązania, } \\
T_{P W}\end{array}$ & $\begin{array}{c}\text { Koniec } \\
\text { wiązania, } \\
T_{K W}\end{array}$ & & \\
\hline & & & & {$[\%]$} & [minuty] & [minuty] & [minuty] & [MPa] \\
\hline 1 & $\begin{array}{c}\text { CEM I 42,5R } \\
\text { w/c }=0,46\end{array}$ & 100 & - & 0,0 & 338 & 532 & 194 & 16,5 \\
\hline 2 & $\begin{array}{c}\text { CEM I 42,5R } \\
\text { w/c }=0,46\end{array}$ & 100 & PG & 4,0 & 443 & 556 & 113 & 14,0 \\
\hline 3 & $\begin{array}{c}\text { CEM I 42,5R } \\
\text { w/c }=0,46\end{array}$ & 100 & BB6 & 4,0 & 355 & 481 & 126 & 20,0 \\
\hline 4 & $\begin{array}{c}\text { CEM I 42,5R } \\
\mathrm{w} / \mathrm{c}=0,46\end{array}$ & 100 & LP102 & 4,0 & 358 & 573 & 215 & 15,5 \\
\hline 5 & $\begin{array}{c}\text { CEM I 42,5R } \\
\text { w/c }=0,46\end{array}$ & 100 & ZKCD & 0,1 & 286 & 412 & 126 & 18,5 \\
\hline
\end{tabular}


środka spowodowała skrócenie czasu zarówno początku, jak i końca wiązania (rys. 3). Skróceniu uległ również czas przejścia od wartości $T_{P W}$ do $T_{K W}$ (rys. 4), a wczesna wytrzymałość na ściskanie była wyższa niż próbki kontrolnej (rys. 5).

$\mathrm{W}$ drugim etapie badaniom podano zaczyny cementowe sporządzone na bazie cementu glinowo-wapniowego firmy REWA. Badania przeprowadzone zostały w analogiczny sposób do poprzedniego cyklu badawczego - współczynnik wodno-cementowy również wynosił 0,46 , a do badań użyto wody wodociągowej. Koncentracja środków przeciwsedymentacyjnych była taka sama jak podczas badań prowadzonych dla cementu klasy CEM I 42,5R. Analizując zestawione w tabeli 2 wyniki badań stwierdzono, że zaczyny sporządzone na bazie cementu glinowo-wapniowego charakteryzują się znacznie krótszymi wartościami czasu wiązania. Próbka kontrolna z zaczynu na bazie cementu glinowo-wapniowego oznaczona nr 6 posiadała czas początku wiązania wynoszący 62 minuty, a koniec wiązania odnotowano po czasie 102 minut. Natomiast w przypadku cementu CEM I 42,5R wartość początku wiązania uzyskano po czasie 338 minut, a wartość końca wiązania po czasie 532 minut (tab. 1). Wprowadzenie środka przeciwsedymentacyjnego PG spowodowało przerwanie procesu hydratacji i zaczyn z 4\%-ową domieszką tego środka nie ulegał związaniu. Obecność kolejnych poddanych badaniom środków
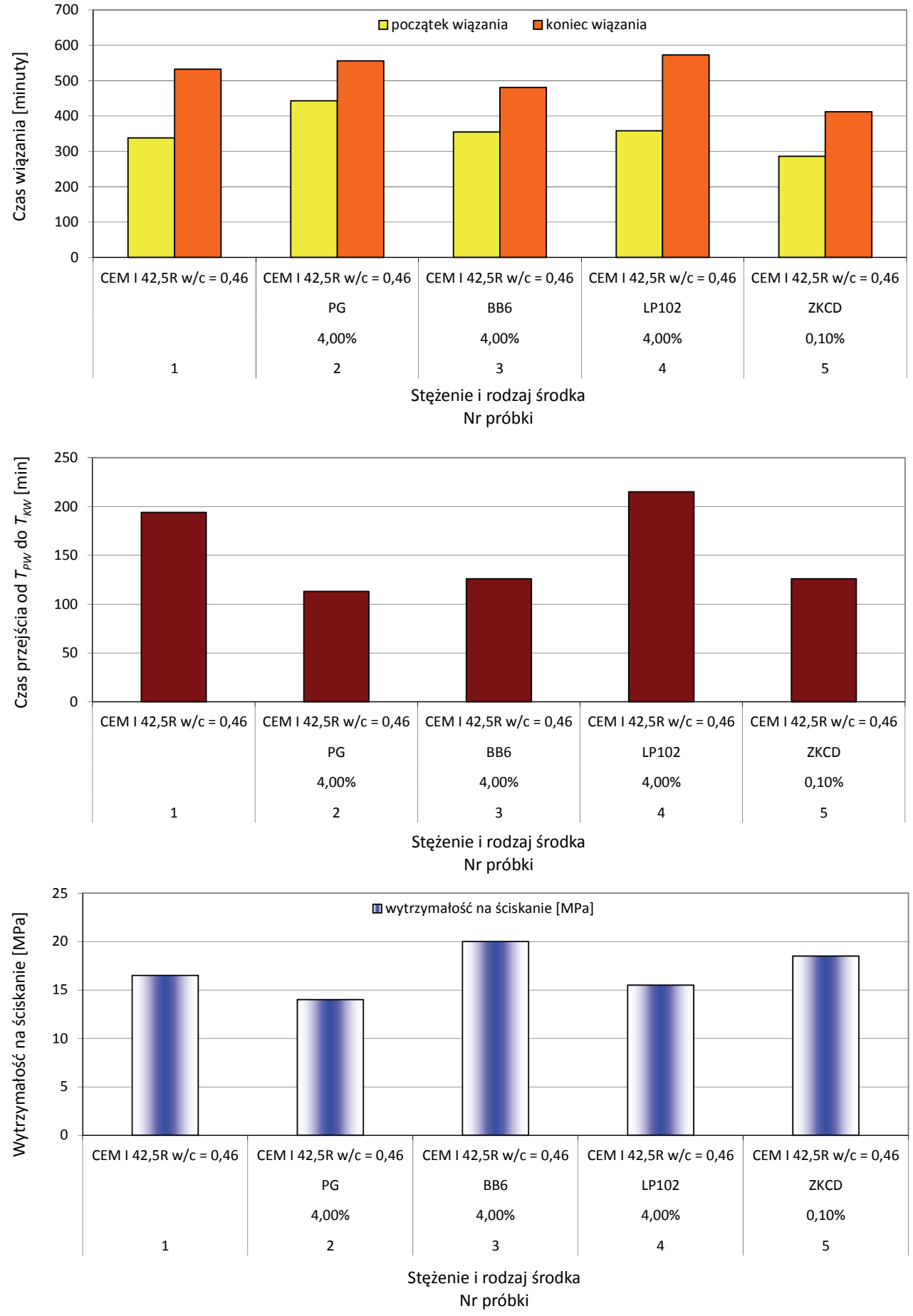

Rys. 3. Zestawienie czasu początku wiązania i czasu końca wiązania badanych próbek z domieszkami o działaniu poprawiającym stabilność sedymentacyjną zaczynu (spoiwo wiążące - cement CEM I 42,5R)

Fig. 3. Comparison of the setting start time and setting end time of the tested samples with admixtures that improve the sedimentation stability of the cement slurry (CEM 42.5R cement)

Rys. 4. Zestawienie wartości przejścia od czasu początku wiązania do czasu końca wiązania badanych próbek z domieszkami o działaniu poprawiającym stabilność sedymentacyjną zaczynu (spoiwo wiążące - cement CEM I 42,5R)

Fig. 4. Comparison of transition values from the start time of setting to the end time of setting of tested samples with admixtures that improve the sedimentation stability of the cement slurry (CEM 42.5R cement)

Rys. 5. Zestawienie wytrzymałości na ściskanie dla próbek zawierających wybrane domieszki o działaniu poprawiającym stabilność sedymentacyjną zaczynu (spoiwo wiążące cement CEM I 42,5R)

Fig. 5. Comparison of compressive strength for samples containing selected admixtures with the effect of improving the sedimentation stability of the cement slurry (CEM 42.5R cement) 
spowodowała wydłużenie wartości czasu początku wiązania w porównaniu do próbki kontrolnej (rys. 6) i czasu końca wiązania. Wyjątkiem był zaczyn nr 9 (rys. 6) zawierający domieszkę środka LP 102, który spowodował skrócenie czasu $T_{K W}$ w porównaniu do próbki kontrolnej. Wartości czasu przejścia od $T_{P W}$ do $T_{K W}$ uległy skróceniu w porównaniu do próbki kontrolnej po zastosowaniu wszystkich z badanych środków przeciwsedymentacyjnych (rys. 7). Wyjątkiem była próbka zawierająca domieszkę środka PG, pod wpływem, którego zaczyn nie związał. Zaobserwowano, że obecność wszystkich z poddanych badaniom środków poprawiających stabilność sedymentacyjną powodowała zmniejszenie wartości wczesnej wytrzymałości mechanicznej w porównaniu do próbki kontrolnej (rys. 8).

Analizując uzyskane wyniki badań stwierdzono, że obecność środków poprawiających stabilność sedymentacyjną wykazuje bardzo zróżnicowane działanie. W próbkach stwardniałych zaczynów na bazie cementu klasy CEM I 42,5R zaobserwowano poprawę parametrów mechanicznych pod wpływem badanych środków przeciwsedymentacyjnych (BB6, ZKCD). Natomiast w próbkach powstałych z zaczynów na bazie cementu glinowo-wapniowego obecność środków przeciwsedymentacyjnych spowodowała obniżenie wartości parametrów mechanicznych lub nawet zatrzymanie procesu hydratacji (domieszka środka PG). Taki wpływ środków poprawiających stabilność sedymentacyjną nie pozostaje bez znaczenia podczas projektowania receptury zaczynów lekkich. To właśnie w zaczynach o obniżonej gęstości problematyczne jest uzyskanie wymaganej wartości wytrzymałości mechanicznej. Ponadto zmiana wartości parametrów mechanicznych pod wpływem środków przeciwsedymentacyjnych, których obecność w zaczynach lekkich jest konieczna, powoduje że zagadnienie dotyczące wpływu domieszek przeciwsedymentacyjnych jest rozwojowe i powinno być realizowane w dalszym ciągu. Pozwoli to w bardziej przewidywalny sposób dobrać rodzaj domieszki do projektowanej receptury zaczynu cementowego.

\section{Wnioski}

Na podstawie zrealizowanych prac badawczych nad zmianą wczesnej wytrzymałości na ściskanie pod wpływem wybranych środków poprawiających stabilność sedymentacyjną sformułowano następujące wnioski końcowe:

1) wprowadzenie do receptury zaczynów cementowych środków poprawiających stabilność sedymentacyjną powoduje bardzo zróżnicowane działania pod kątem zmiany wartości czasu wiązania zaczynu oraz uzyskiwanych parametrów mechanicznych stwardniałego zaczynu cementowego;

2) najmocniejsze skrócenie czasu przejścia od czasu początku wiązania do czasu końca wiązania w zaczynie na bazie cementu klasy CEM I 42,5R widoczne było pod wpływem 4\%-owej koncentracji środka PG;

3) środek przeciwsedymentacyjny PG zastosowany w zaczynie na bazie cementu klasy CEM I 42,5R spowodował również zmniejszenie wartości wczesnej wytrzymałości mechanicznej w porównaniu do próbki kontrolnej;

4) najmocniejsze działanie poprawiające wartość wczesnej wytrzymałości na ściskanie w zaczynie na bazie cementu portlandzkiego klasy CEM I 42,5R wykazywał środek przeciwsedymentacyjny BB6;

5) zastosowanie domieszki przeciwsedymentacyjnej LP 102 w zaczynie na bazie cementu klasy CEM I 42,5R spowodowało wydłużenie czasu początku wiązania końca wiązania

Tabela 2. Badania różnego rodzaju środków o działaniu poprawiającym stabilność sedymentacyjną zaczynu (spoiwo wiążące - cement glinowy Rewa)

Table 2. Tests of various types of agents that improve the sedimentation stability of the cement slurry (Rewa aluminum cement)

\begin{tabular}{|c|c|c|c|c|c|c|c|c|}
\hline \multirow{3}{*}{$\begin{array}{c}\mathrm{Nr} \\
\text { próbki }\end{array}$} & \multirow{3}{*}{$\begin{array}{c}\text { Rodzaj cementu = } \\
\text { Współczynnik } \\
\text { wodno-cementowy }\end{array}$} & \multirow[b]{2}{*}{$\begin{array}{c}\text { Udzial } \\
\text { cementu }\end{array}$} & \multirow{3}{*}{$\begin{array}{c}\text { Rodzaj } \\
\text { domieszki }\end{array}$} & \multirow[b]{2}{*}{$\begin{array}{c}\text { Udzial } \\
\text { domieszki }\end{array}$} & \multicolumn{2}{|c|}{ Czas wiązania } & \multirow{2}{*}{$\begin{array}{c}\text { Czas } \\
\text { przejścia } \\
\text { od PW do KW }\end{array}$} & \multirow{2}{*}{$\begin{array}{l}\text { Wytrzymałość na } \\
\text { ściskanie (średnia } \\
\text { arytmetyczna) } \\
2 \text { dni hydratacji }\end{array}$} \\
\hline & & & & & $\begin{array}{c}\text { Początek } \\
\text { wiązania, } \\
T_{P W}\end{array}$ & $\begin{array}{c}\text { Koniec } \\
\text { wiązania, } \\
T_{K W}\end{array}$ & & \\
\hline & & {$[\%]$} & & {$[\%]$} & [minuty] & [minuty] & [minuty] & [MPa] \\
\hline 6 & $\begin{array}{c}\text { CEM REWA } \\
\mathrm{w} / \mathrm{c}=0,46\end{array}$ & 100 & - & 0,0 & 62 & 102 & 40 & 15,5 \\
\hline 7 & $\begin{array}{l}\text { CEM REWA } \\
\mathrm{w} / \mathrm{c}=0,46\end{array}$ & 100 & PG & 4,0 & - & - & - & nie wiąże \\
\hline 8 & $\begin{array}{c}\text { CEM REWA } \\
\mathrm{w} / \mathrm{c}=0,46\end{array}$ & 100 & BB6 & 4,0 & 76 & 112 & 36 & 11,0 \\
\hline 9 & $\begin{array}{l}\text { CEM REWA } \\
\mathrm{w} / \mathrm{c}=0,46\end{array}$ & 100 & LP102 & 4,0 & 74 & 91 & 17 & 10,0 \\
\hline 10 & $\begin{array}{l}\text { CEM REWA } \\
\mathrm{w} / \mathrm{c}=0,46\end{array}$ & 100 & $\mathrm{ZKCD}$ & 0,1 & 91 & 111 & 20 & 10,5 \\
\hline
\end{tabular}




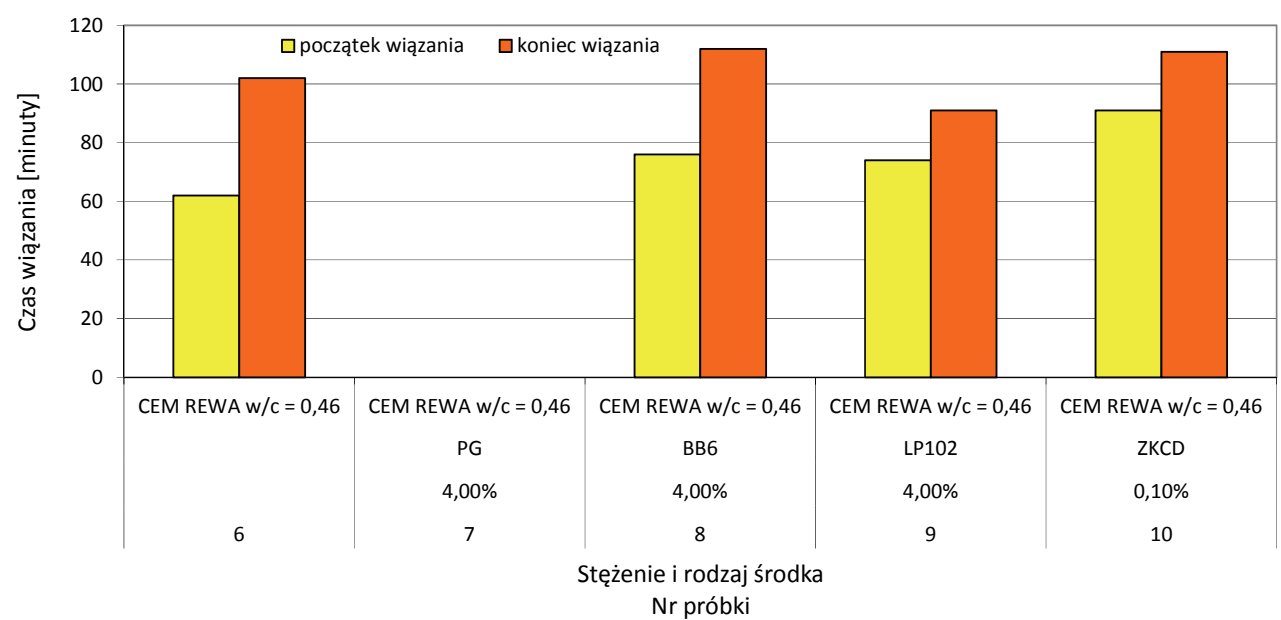

Rys. 6. Zestawienie czasu początku wiązania i czasu końca wiązania badanych próbek z domieszkami o działaniu poprawiającym stabilność sedymentacyjną zaczynu (spoiwo wiążące - cement glinowy Rewa)

Fig. 6. Comparison of setting start time and setting end time of tested samples with admixtures that improve the sedimentation stability of the cement slurry (Rewa aluminum cement)

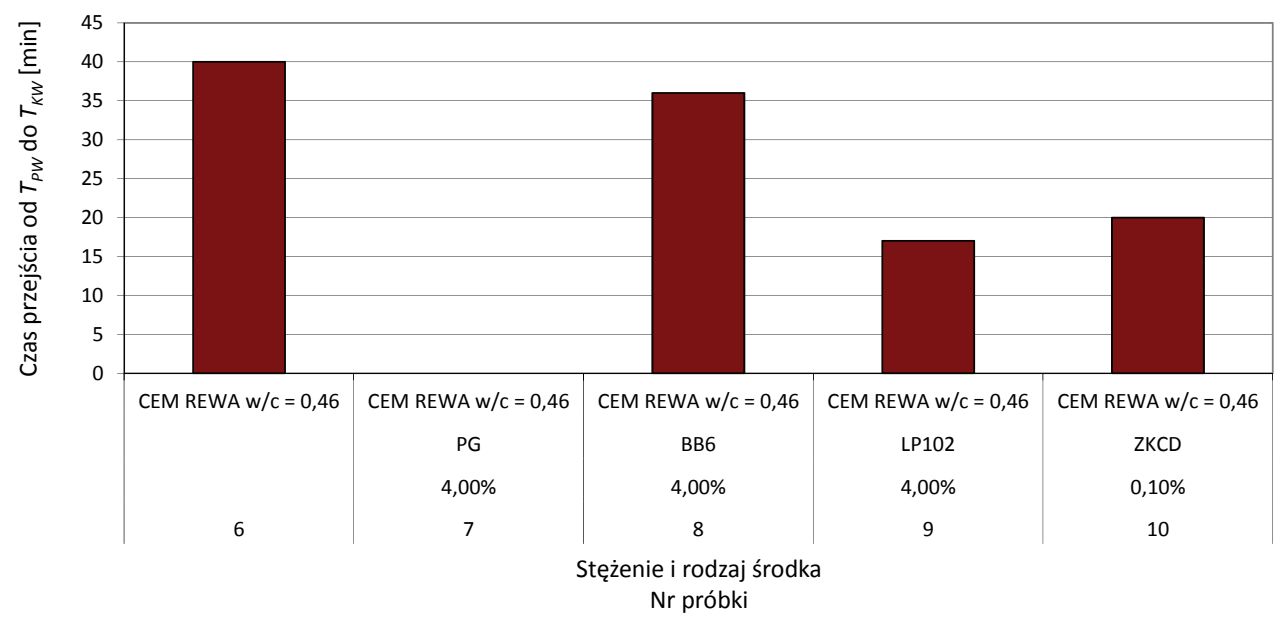

Rys. 7. Zestawienie wartości przejścia od czasu początku wiązania do czasu końca wiązania badanych próbek z domieszkami o działaniu poprawiającym stabilność sedymentacyjną zaczynu (spoiwo wiążące - cement glinowy Rewa)

Fig. 7. Summary of transition values from the time of start of binding to the time of end of binding of tested samples with admixtures having the effect of improving the sedimentation stability of the cement slurry (Rewa aluminum cement)

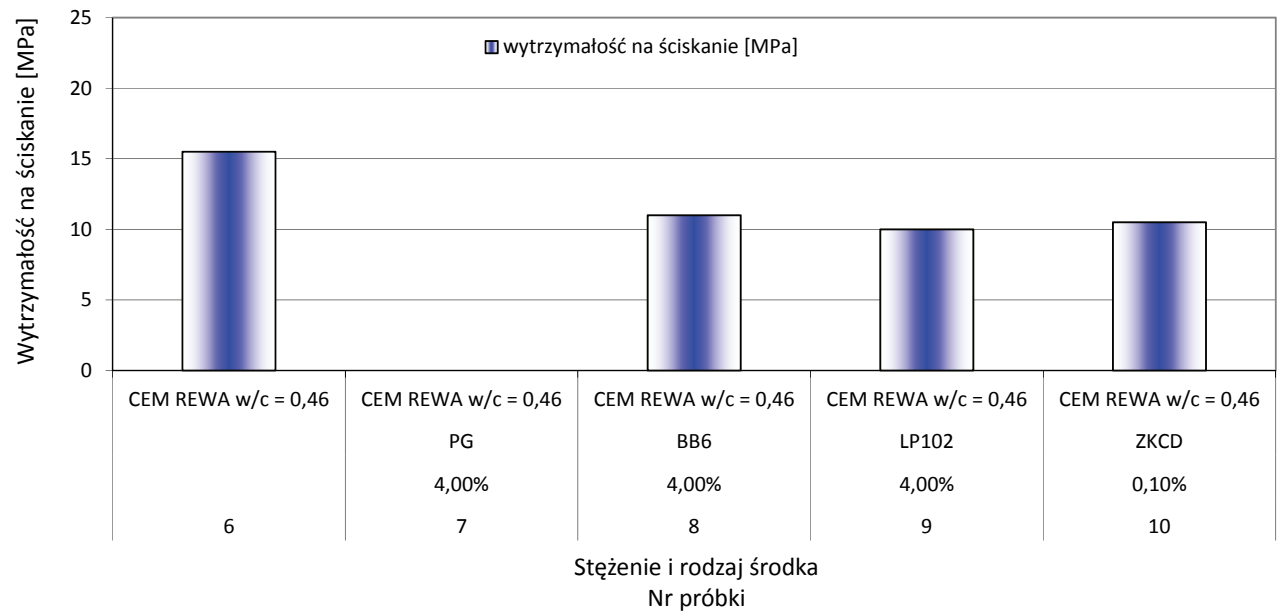

Rys. 8. Zestawienie wytrzymałości na ściskanie dla próbek $\mathrm{z}$ domieszkami o działaniu poprawiającym stabilność sedymentacyjną zaczynu (spoiwo wiążące - cement glinowy Rewa)

Fig. 8. Comparison of compressive strength for samples with admixtures that improve the sedimentation stability of the cement slurry (Rewa aluminum cement)

i czasu przejścia od PW do KW, a dodatkowo wczesna wytrzymałość uległa obniżeniu w porównaniu do próbki kontrolnej;

6) zastosowanie ZCKD w zaczynie na bazie cementu klasy CEM I 42,5R powodowało skrócenie czasu początku wiązania i końca wiązania oraz czasu przejścia, a wartość wczesnej wytrzymałości na ściskanie uległa wzrostowi w porównaniu do próbki kontrolnej;

7) obecność środka LP102 spowodowała zatrzymanie procesu hydratacji zaczynu na bazie cementu glinowo-wapniowego, zaczyn nie związał i środek ten nie może być stosowany w recepturach zaczynów na bazie cementów szybkowiążących (zawierających tlenek glinu);

8) zastosowanie środków przeciwsedymentacyjnych w próbkach zaczynów sporządzonych na bazie cementu glinowo-wapniowego spowodowały skrócenie czasu początku wiązania oraz czasu przejścia od $T_{P W}$ do $T_{K W}$ w porównaniu do próbki kontrolnej;

9) obecność badanych środków przeciwsedymentacyjnych w zaczynach na bazie cementu glinowo-wapniowego skutkowała obniżeniem wartości wczesnej wytrzymałości mechanicznej. 
Artykuł powstał na podstawie pracy badawczej pt.: Analiza możliwości doszczelnienia mikrostruktury płaszcza cementowego za pomoca nowych domieszek drobnoziarnistych - praca INiG - PIB na zlecenie MNiSW, nr zlecenia: 0044/KW/19, nr archiwalny: DK-4100-34/19.

\section{Literatura}

Bensted J., 1978. Effect of Accelerator Additives on the Early Hydratation of Portland Cement. Il Cemento: 13-20.

Bensted J., 2004. Cementy wiertnicze. Cz. 2. Stosowanie cementów wiertniczych do cementowania odwiertów. Cement Wapno Beton, 2: 61-72.

Carathers K., Crook R., 1987. Surface Pipe Cement Gives High Earsly Strength With New Cement Additive. Proc. South-wester Petroleum Short Course, Lubbock. TX: 12-19.

Falode O.A., Salam K.K., Arinkoola A.O., Ajagbe B.M., 2013. Prediction of compressive strength of oil field class G cement slurry using factorial design. Journal of Petroleum Exploration and Production Technology, 3(4): 297-302.

Herianto A., Fathaddin M.T., 2005. Effects of additives and conditioning time on comprehensive and shear bond strengths of geothermal well cement. Proceedings of World Geothermal Congress, Antalya, Turkey: 1-7.

Jordan A., Pernites R., Albrighton L., 2018. Low-density, lightweight cement tested as alternative to reduce lost circulation, achieve desired top of cement in long horizontal wells. Drillingcontactor, September/ October: 62-64.

Kremieniewski M., 2017. Poprawa stabilności sedymentacyjnej zaczynu cementowego. Nafta-Gaz, 4: 242-249. DOI: 10.18668/NG.2017.04.04.

Kremieniewski M., 2018a. Poprawa wczesnej wytrzymałości mechanicznej płaszcza cementowego powstałego z zaczynu lekkiego. Nafta-Gaz, 8: 599-605. DOI: 10.18668/NG.2018.08.06.

Kremieniewski M., 2018b. Wpływ środków regulujących czas wiązania na parametry reologiczne zaczynu cementowego. Nafta-Gaz, 11: 828-838. DOI: 10.18668/NG.2018.11.07.

Kremieniewski M., 2018c. Zmiana parametrów technologicznych zaczynu cementowego pod wpływem przeciwsedymentacyjnego dodatku żywicy ksantanowej. Nafta-Gaz, 12: 927-937. DOI: 10.18668/ NG.2018.12.07.

Kremieniewski M., 2019a. Receptury zaczynów do uszczelniania kolumn rur posadowionych w otworach wierconych w skałach chłonnych. Nafta-Gaz, 8: 451-457. DOI: 10.18668/NG.2019.08.01.

Kremieniewski M., 2019b. Rola plastyfikatora w projektowaniu zaczynu lekkiego o podwyższonej stabilności sedymentacyjnej. Nafta-Gaz, 9: 571-578. DOI: 10.18668/NG.2019.09.06.

Kremieniewski M., 2019c. Korelacja wyników badań filtracji i wczesnej wytrzymałości mechanicznej zaczynów cementowych z dodatkiem mączki krzemionkowej. Nafta-Gaz, 7: 394-403. DOI: 10.18668/ NG.2019.07.03.

Kremieniewski M., 2019d. Receptury zaczynów do uszczelniania kolumn rur posadowionych w otworach wierconych w skałach chłonnych. Nafta-Gaz, 8: 451-457. DOI: 10.18668/NG.2019.08.01.

Kremieniewski M., 2019e. Korelacja wyników badań wytrzymałości na ściskanie i przyczepności do rur stalowych płaszcza cementowego z zaczynu o obniżonej gęstości. Nafta-Gaz, 10: 613-624. DOI: 10.18668/NG.2019.10.03.

Kremieniewski M., 2019f. Wpływ drobnoziarnistej krzemionki na parametr czasu oczekiwania na cement - WOC. Nafta-Gaz, 11: 683-690. DOI: 10.18668/NG.2019.11.03.

Kremieniewski M., Kędzierski M., 2019. Badanie frakcjonowania lekkich materiałów obniżających gęstość jako wstępnego parametru podczas projektowania receptury zaczynu lekkiego. Nafta-Gaz, 12: 35-42. DOI: 0.18668/NG.2019.12.04.

Kremieniewski M., Stryczek S., 2019. Zastosowanie cementu wysokoglinowego do sporządzania zaczynów uszczelniających w technologiach wiertniczych. Cement Wapno Beton, 3: 215-226.
Kremieniewski M., Stryczek S., Wiśniowski R., Gonet A., 2016. Zmniejszanie porowatości stwardniałych zaczynów wiertniczych poprzez wprowadzenie dodatków drobnoziarnistych. Cement Wapno Beton, 5, 325-335.

Kurdowski W., 2010. Chemia cementu i betonu. Wydawnictwo Naukowe PWN, Warszawa. 1-700.

Labibzadeh M., Zahabizadeh B., Khajehdezfuly A., 2010. Early-age compressive strength assessment of oil well class $\mathrm{G}$ cement due to borehole pressure and temperature changes. Journal of American Science, 6(7): 38-45.

Lapasin R., De Lorenzi L., Pricl S., Torriano G., 1995. Flow properties of hydroxypropyl guar gum and its long-chain hydrophobic derivatives. Carbohydrate Polymer, 28(3), 195-202.

Nelson E.B. (ed.), 1990. Well Cementing, Schlumberger Educational Service, Houston, Teksas, USA.

Półchłopek T. (kier. zespołu), 1993. Zaczyny cementowe do cementowania otworów kierunkowych i poziomych oraz technologia ich zatłaczania. Praca INiG; Archiwum Instytutu Nafty i Gazu - Państwowego Instytutu Badawczego, Kraków.

Peng Y, Jacobsen S., 2013. Influence of water/cement ratio, admixtures and filler on sedimentation and bleeding of cement paste. Cement and Concrete Research, 54: 133-142. DOI: 10.1016/j.cemconres.2013.09.003.

Raczkowski J., Stryczek S., Fugiel K., Kraj Ł., Wilk S., 1978. Zaczyny do uszczelniania w otworach wiertniczych. Skrypty uczelniane, Akademia Górniczo-Hutnicza, Kraków: 1-311.

Risica D., Barbetta A., Vischetti L., Cametti C., Dentini M., 2010. Rheological properties of guar and its methyl, hydroxypropyl and hydroxypropyl-methyl derivatives in semidilute and concentrated aqueous solutions. Polymer, 51(9), 1972-1982.

Rzepka M., Kremieniewski M., Dębińska E., 2012. Zaczyny cementowe przeznaczone do uszczelniania eksploatacyjnych kolumn rur okładzinowych na Niżu Polskim. Nafta-Gaz, 8: 512-522.

Rzepka M., Stryczek S., 2008. Laboratoryjne metody określania parametrów technologicznych świeżych zaczynów uszczelniających przed zabiegiem związanym z procesem uszczelniania kolumn rur okładzinowych w otworach wiertniczych. Wiertnictwo, Nafta, Gaz, 25(2), 625-636.

Stryczek S., Gonet A., Wiśniowski R., 2005. Wpływ wybranego dodatku mineralnego na własności technologiczne zaczynów cementowych. Wiertnictwo, Nafta, Gaz, 22(1): 333-341.

Stryczek S., Gonet A., Wiśniowski R., Złotkowski A., 2011. Zaczyny uszczelniające do wypełniania pustek w górotworze solnym. Wiertnictwo, Nafta, Gaz, 28(1-2): 391-400.

Stryczek S., Wiśniowski R., Gonet A., Ferens W., 2009. Parametry reologiczne świeżych zaczynów uszczelniających w zależności od czasu ich sporządzania. Wiertnictwo, Nafta, Gaz, 26/1-2: 369-382.

Stryczek S., Wiśniowski R., Gonet A., Złotkowski A., 2014. The influence of time of rheological parameters of fresh cement slurries. $A G H$ Drilling, Oil, Gas, 31: 123-133. DOI: 10.7494/drill.2014.31.1.123.

Stryczek S.(red.), Kotwica Ł., Kremieniewski M., Rzepka M., UliaszMisiak B., Wiśniowski R., Złotkowski A., 2016. Studia nad doborem zaczynów uszczelniających w warunkach wierceń w basenie pomorskim. Wydawnictwo AGH, Kraków.

Wiśniowski R., Stryczek S., Skrzypaszek K., 2007. Kierunki rozwoju badań nad reologią płynów wiertniczych. Wiertnictwo, Nafta, Gaz, 24: 595-607.

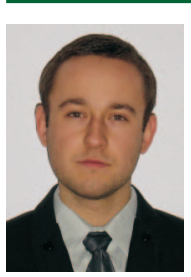

Dr inż. Marcin KREMIENIEWSKI

Adiunkt w Zakładzie Technologii Wiercenia Instytut Nafty i Gazu - Państwowy Instytut Badawczy ul. Lubicz 25 A

31-503 Kraków

E-mail: marcin.kremieniewski@inig.pl 